\title{
Glycation and phosphorylation of $\alpha$-lactalbumin by dry heating: Effect on protein structure and physiological functions
}

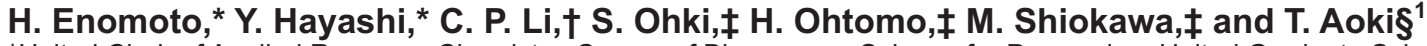 \\ *United Chair of Applied Resource Chemistry, Course of Bioresource Science for Processing, United Graduate School of Agricultural Sciences, \\ Kagoshima University, Kagoshima 890-0065, Japan \\ †Department of Food and Pharmacy Engineering, School of Chemistry Science and Technology, Yunnan University, Kunming 650091, China \\ ‡Food Technology Research Institute, Division of Research and Development, Meiji Dairies Corporation, 540 Naruda, Odawara, \\ Kanagawa 250-0862, Japan \\ §Department of Biochemical Science and Technology, Faculty of Agriculture, Kagoshima University, Kagoshima 890-0065, Japan
}

\section{ABSTRACT}

$\alpha$-Lactalbumin ( $\alpha$-LA) was glycated with maltopentaose (MP) through the Maillard reaction (MP- $\alpha-L A)$ and subsequently phosphorylated by dry heating in the presence of pyrophosphate to investigate its structure and physiological functions. Glycation occurred effectively, and the sugar content of $\alpha$-LA increased by approximately $22.3 \%$ through the Maillard reaction. The phosphorylation of MP- $\alpha$-LA was enhanced with an increase in the dry-heating time from 1 to $5 \mathrm{~d}$, and the phosphorous content of MP- $\alpha$-LA increased by approximately $1.01 \%$ by dry heating at $\mathrm{pH} 4.0$ and $85^{\circ} \mathrm{C}$ for $5 \mathrm{~d}$ in the presence of pyrophosphate. The electrophoretic mobility of $\alpha$-LA increased with an increase in the phosphorylation level. The circular dichroism spectra showed that the change in the secondary structure of the $\alpha$-LA molecule by glycation and subsequent phosphorylation was slight. However, the Trp fluorescence intensity was increased by phosphorylation after glycation. In addition, the differential scanning calorimetry thermograms of $\alpha$-LA showed that the denaturation temperature of MP- $\alpha$-LA was decreased by phosphorylation. These results indicated that molten (partially unfolded) conformations of $\alpha$-LA were formed by dry heating in the presence of pyrophosphate after glycation. The anti- $\alpha-L A$ antibody response was significantly reduced by glycation and subsequent phosphorylation. The suppressive effect of $\alpha$-LA on the production of proinflammatory cytokines such as IL- 6 and tumor necrosis factor- $\alpha$ from THP-1 cells after stimulation with lipopolysaccharide was significantly enhanced by glycation with MP and was further enhanced by phosphorylation after glycation. The Ca phosphate-solubilizing ability of $\alpha$-LA was enhanced by phosphorylation. The apoptotic activity of $\alpha$-LA was reduced by glycation

Received January 5, 2009

Accepted February 27, 2009.

${ }^{1}$ Corresponding author: aoki@chem.agri.kagoshima-u.ac.jp and subsequent phosphorylation. These results suggest that phosphorylation by dry heating in the presence of pyrophosphate after glycation with MP through the Maillard reaction is a useful method for improvement of the physiological functions of $\alpha$-LA.

Key words: $\alpha$-lactalbumin, glycation, phosphorylation, physiological function

\section{INTRODUCTION}

Phosphorylation has been proved to be a useful method for improving the functional properties of food proteins. The functional properties of some phosphorylated proteins have been studied and reviewed by Matheis and Whitaker (1984). Over the past few decades, several phosphorylation methods have been reported by researchers (Seguro and Motoki, 1989; Aoki et al., 1994, 1997; Kato et al., 1995; Sitohy et al., 1995; Vojdani and Whitaker, 1996; Chobert, 2003). However, these phosphorylation methods have posed some problems (Li et al., 2003), making them very difficult to put to practical use. Li et al. (2003, 2004) phosphorylated egg white protein by dry heating in the presence of phosphate, significantly improving some functional properties. However, whey protein isolate (WPI) showed a lower phosphorylation level than egg white protein by dry heating under the same conditions, presumably because of a lower sugar content of WPI (Li et al., 2003). We then attempted to prepare phosphorylated WPI by glycation with maltopentaose (MP) through the Maillard reaction and subsequent phosphorylation by dry heating in the presence of pyrophosphate, with the result that some functional properties, such as heat stability, emulsifying properties, and gelling properties, were improved by glycation and subsequent phosphorylation (Li et al., 2005a). Furthermore, the Ca phosphate-solubilizing ability of WPI was enhanced by phosphorylation, and the antigenicity of $\beta-\mathrm{LG}$ and BSA, major allergens in WPI, was significantly reduced by glycation and subsequent phosphorylation (Enomoto et al., 2007, 2008). 
$\alpha$-Lactalbumin is a $14.2-\mathrm{kDa}$ Ca-binding protein with 4 disulfide bonds (Permyakov and Berliner, 2000). The structure of $\alpha$-LA is divided into the $\alpha$-domain and the $\beta$-domain by a deep cleft (Permyakov and Berliner, 2000). Calcium binding to the strong Cabinding site increases the stability of the native form of $\alpha$-LA (Permyakov and Berliner, 2000). $\alpha$-Lactalbumin undergoes partial unfolding to form a molten globule at low $\mathrm{pH}$ or by the removal of $\mathrm{Ca}$ at neutral $\mathrm{pH}$ and slightly denaturing conditions (Permyakov and Berliner, 2000). Regarding the physiological functions, it is well-known that $\alpha$-LA is one of the 2 components of lactose synthase, which catalyzes the final step in lactose biosynthesis in the lactating mammary gland (Brodbeck et al., 1967). Recently, it has been reported that $\alpha$-LA and its hydrolysate have many physiological functions, such as reduction of stress (Markus et al., 2000), antimicrobial activity (Pellegrini et al., 1999), opioid activity (Nagendra, 2000), antihypertensive action (FitzGerald et al., 2004), regulation of cell growth (Sternhagen and Allen, 2001), antiulcer activity (Matsumoto et al., 2001), and immunomodulation (Cross and Gill, 2000). Svensson et al. (2000) showed that $\alpha$-LA derived from human whey could be converted to the apoptotic-inducing form when removing bound $\mathrm{Ca}$, by treatment with EDTA, and passing it through an anion-exchange column previously conditioned with oleic acid. The active form of the protein, called "human $\alpha$-LA made lethal to tumor cells" (HAMLET), was described as a complex formed by apo- $\alpha$-LA and oleic acid (Svensson et al., 2000). The HAMLET induces apoptosis (programmed cell death) in tumor cells but spares mature cells (Svensson et al., 2000). Bovine $\alpha$-LA or the $\alpha$-LA of other species, together with oleic acid, can be converted to HAMLET-like complexes by the same method (Pettersson et al., 2006). It was also demonstrated that whey protein or $\alpha$-LA had a marked suppressive effect against the increased release of proinflammatory cytokines, such as IL-1, IL-6, and tumor necrosis factor- $\alpha$ (TNF- $\alpha$ ), from the D-galactosamineinduced liver injury rat model or ischemia/reperfusioninduced intestinal injury rat model (Kume et al., 2006; Yamaguchi and Uchida, 2007). $\alpha$-Lactalbumin is a second major whey protein in WPI, and its behavior affects the functional properties of WPI.

In the present study, we phosphorylated $\alpha$-LA by dry heating in the presence of pyrophosphate after glycation with MP through the Maillard reaction to investigate protein structure and physiological functions of phosphorylated $\alpha$-LA. Because $\alpha$-LA is well-known as a major allergen in milk (Maynard et al., 1997), the effects of glycation and subsequent phosphorylation on the antigenicity of $\alpha$-LA were also examined.

\section{MATERIALS AND METHODS}

\section{Materials}

Quaternary aminoethyl-Toyopearl was purchased from Tosoh Co. Inc. (Tokyo, Japan). An adult male Japanese white rabbit (JW/CSK) was purchased from Charles River Japan Inc. (Yokohama, Japan). Interferon- $\gamma$, phorbol 12-myristate 13-acetate, RPMI1640 medium, and LPS from Salmonella Minnesota were purchased from Sigma-Aldrich (St. Louis, MO). Fetal bovine serum (FBS) was purchased from EquitechBio Inc. (Kerrville, TX). The FBS was inactivated by heating before the experiment. Maltopentaose, sodium pyruvate, gentamicin, gelatin, oleic acid, and trypan blue solution were purchased from Nacalai Tesque Co. Inc. (Kyoto, Japan). All other reagents were of analytical grade.

The crude $\alpha$-LA was isolated from raw skim milk according to the method of Armstrong et al. (1967) and purified by column chromatography with quaternary aminoethyl-Toyopearl. To make the $\alpha$-LA into holoform, $\mathrm{CaCl}_{2}$ was added in the crude $\alpha$-LA solution and dialyzed against $50 \mathrm{~m} M$ Tris- $\mathrm{HCl}$ buffer ( $\mathrm{pH}$ 8.5). The crude $\alpha$-LA solution was applied to the column and eluted by 0 to $300 \mathrm{mM} \mathrm{NaCl}$ linear gradient in the same buffer at $1.0 \mathrm{~mL} / \mathrm{min}$ according to the modified method of Ye et al. (2000). The major fraction was dialyzed against deionized water and then lyophilized. The purity of $\alpha$-LA was confirmed by SDS-PAGE according to the method of Laemmli (1970); the prepared $\alpha$-LA was holo-form.

\section{Preparation of Glycated and Phosphorylated a-LA}

Native $\alpha$-LA (N- $\boldsymbol{\alpha}-\mathbf{L A})$ and MP (1:0.5 wt/wt) were dissolved in deionized water at a protein concentration of $20 \mathrm{~g} / \mathrm{L}$, and the solution $\mathrm{pH}$ was adjusted to 8.0 with $1 \mathrm{M} \mathrm{NaOH}$, followed by lyophilization. The dried sample was kept at $50^{\circ} \mathrm{C}$ and $65 \%$ relative humidity (RH) for $3 \mathrm{~d}$ using a saturated KI solution in a desiccator according to a previously published method (Aoki et al., 2001), and was then dissolved in $0.1 \mathrm{M}$ sodium pyrophosphate buffer at $\mathrm{pH}$ 4.0. The lyophilized sample was incubated at $85^{\circ} \mathrm{C}$ for 1 and $5 \mathrm{~d}$, and the dryheated samples were then dissolved in deionized water. The solution was dialyzed to remove free MP and pyrophosphate for $3 \mathrm{~d}$ against deionized water and then lyophilized (PP-MP- $\mathbf{\alpha}-\mathbf{L} \mathbf{A})$.

In comparison with $\mathrm{PP}-\mathrm{MP}-\alpha-\mathrm{LA}, \mathrm{MP}$-conjugated $\alpha-L A(\mathbf{M P}-\boldsymbol{\alpha}-\mathbf{L A})$ and dry-heated $\alpha-\mathrm{LA}(\mathbf{D H}-\boldsymbol{\alpha}-\mathbf{L A})$ were prepared. To prepare MP- $\alpha-L A, N-\alpha-L A$ and MP (1:0.5 wt/wt) were dissolved in deionized water at a protein concentration of $20 \mathrm{~g} / \mathrm{L}$, and the $\mathrm{pH}$ value of the 
solution was adjusted to 8.0 with $1 \mathrm{M} \mathrm{NaOH}$, followed by lyophilization. The dried sample was kept at $50^{\circ} \mathrm{C}$ $(65 \% \mathrm{RH})$ for $3 \mathrm{~d}$ using a saturated KI solution in a desiccator, and then dialyzed against deionized water for 3 $\mathrm{d}$, after which the solution was lyophilized. To prepare $\mathrm{DH}-\alpha-\mathrm{LA}, \mathrm{N}-\alpha-\mathrm{LA}$ was dissolved in deionized water at a concentration of $20 \mathrm{~g} / \mathrm{L}$, and the $\mathrm{pH}$ was adjusted to $\mathrm{pH} 8.0$ with $1 \mathrm{M} \mathrm{NaOH}$, followed by lyophilization. The dried sample was kept at $50^{\circ} \mathrm{C}(65 \% \mathrm{RH})$ for $3 \mathrm{~d}$ using a saturated KI solution in a desiccator, and was then dissolved in deionized water at a concentration of $20 \mathrm{~g} / \mathrm{L}$, and the $\mathrm{pH}$ was adjusted to 4.0 with $1 M \mathrm{HCl}$, followed by lyophilization. The lyophilized sample was incubated at $85^{\circ} \mathrm{C}$ for $5 \mathrm{~d}$, after which the solution was lyophilized.

\section{Determination of Sugar Content}

The total sugar contents of $\mathrm{N}-, \mathrm{DH}-, \mathrm{MP}-$, and $\mathrm{PP}-\mathrm{MP}-\alpha-\mathrm{LA}$ were determined by the phenol-sulfuric acid method (Dubois et al., 1956). For the determination of free sugar, $2 \mathrm{~mL}$ of a $2 \mathrm{~g} / \mathrm{L}$ sample solution was ultrafiltered through Centrisalt I (AG-W-3400, Sartorius, Goettingen, Germany; molecular mass cutoff $=10,000)$. The sugar content in the ultrafiltrate was regarded as free sugar. The sugar bound to $\alpha-\mathrm{LA}$ was estimated by the difference between the total and free sugar content.

\section{Determination of $P$ Content}

Protein samples were digested in perchloric acid. Phosphorus in the digest was regarded as the total $\mathrm{P}$ of protein. For the determination of inorganic $\mathrm{P}(\mathbf{P i}), 2$ $\mathrm{mL}$ of $2 \mathrm{~g} / \mathrm{L}$ sample solution was ultrafiltered through Centrisalt I (AG-W-3400, Sartorius; molecular mass cut off $=10,000)$. The $\mathrm{P}$ content in the ultrafiltrate was regarded as $\mathrm{Pi}$. The $\mathrm{P}$ content was determined by the method of Chen et al. (1956). The amount of $\mathrm{P}$ bound to proteins was estimated by the difference between the total $\mathrm{P}$ and $\mathrm{Pi}$ content.

\section{Measurement of Solubility}

Protein samples were dissolved at a protein concentration of $1 \mathrm{~g} / \mathrm{L}$ in $50 \mathrm{~m} M$ Tris- $\mathrm{HCl}$ buffer $(\mathrm{pH} 7.0)$, and then centrifuged at $1,000 \times g$ for $15 \mathrm{~min}$. The concentration of protein in the supernatant was determined using the method of Lowry et al. (1951).

\section{Electrophoresis}

Native PAGE was performed using $15.0 \%$ gels in the absence of SDS, and SDS-PAGE was performed using
$15.0 \%$ gels under both reducing and nonreducing conditions in the presence and absence of 2-mercaptoethanol (2-ME) according to the method of Laemmli (1970). The gels were stained in Coomassie Brilliant Blue R-250 for $1 \mathrm{~h}$.

\section{Circular Dichroism Spectra}

Circular dichroism (CD) spectra were measured at 190 to $250 \mathrm{~nm}$ with a Jasco J-820 spectropolarimeter (Jasco Co., Tokyo, Japan) using a cell with a 1.0-mm path length, and the digitized data were transferred to a microcomputer and processed. An average of 5 scans was recorded. Samples were dissolved in $50 \mathrm{mM}$ phosphate buffer $(\mathrm{pH}$ 7.0) at a protein concentration of $0.1 \mathrm{~g} / \mathrm{L}$. Circular dichroism spectra were represented in terms of mean residue ellipticity (degrees $\mathrm{cm}^{2} / \mathrm{dmol}$ ). The protein concentration in the solution was determined using the method of Lowry et al. (1951).

\section{Trp Fluorescence Spectra}

Tryptophan fluorescence intensity (FI) of protein samples was scanned at emissions from 300 to $400 \mathrm{~nm}$ excited at a wavelength of $280 \mathrm{~nm}$ by an FP-6600 fluorescence spectrophotometer (Jasco Co.) at $25^{\circ} \mathrm{C}$. Each sample was dissolved in $50 \mathrm{~m} M$ phosphate buffer ( $\mathrm{pH}$ 7.0) at a protein concentration of $0.1 \mathrm{~g} / \mathrm{L}$. The protein concentration in the solution was determined using the method of Lowry et al. (1951).

\section{Differential Scanning Calorimetry}

Differential scanning calorimetry (DSC) was performed in a VP-DSC Microcalorimeter (MicroCal, Northampton, MA). Before the DSC experiments, samples were dialyzed against $20 \mathrm{~m} M$ phosphate buffer ( $\mathrm{pH}$ 7.4). After being filtered through a $0.22-\mu \mathrm{m}$ filter, samples and reference solutions were properly degassed and loaded into the calorimeter. The experiments were carried out under an extra pressure of 1 atm to avoid degassing during heating. The calorimetric data were analyzed using Origin software provided with the calorimeter. The protein concentration was $1 \mathrm{~g} / \mathrm{L}$ and was heated in the calorimeter at a scan rate of $1^{\circ} \mathrm{C} / \mathrm{min}$ over a range of 30 to $80^{\circ} \mathrm{C}$. The protein concentration in the solution was determined using the method of Lowry et al. (1951).

\section{Immunization}

An adult male JW/CSK rabbit was immunized subcutaneously with $\alpha$-LA emulsified in Freund's complete adjuvant (Difco Laboratories, Detroit, MI). One month 
after the primary immunization, the rabbit was boosted with $\alpha$-LA emulsified in Freund's incomplete adjuvant (Difco Laboratories). Blood samples were collected 1 wk after the secondary immunizations and stored at $4^{\circ} \mathrm{C}$ for $24 \mathrm{~h}$ to form a clot. Antiserum was prepared from the sample after clot formation and verified by the double-diffusion test of Ouchterlony (1949).

\section{ELISA}

A noncompetitive ELISA was carried out according to the method in a previous paper (Enomoto et al., 2007). $\alpha$-Lactalbumin samples dissolved in PBS at a protein concentration of $0.1 \mathrm{~g} / \mathrm{L}(100 \mu \mathrm{L})$ were added to the wells of a polystyrene microtitration plate (Maxisorp, Nunc A/S, Roskilde, Denmark), and the plate was incubated at $4^{\circ} \mathrm{C}$ overnight to coat the wells with each antigen. After removal of the solution, each well was washed 3 times with $120 \mu \mathrm{L}$ of PBS-Tween (PBS containing $0.5 \mathrm{~g} / \mathrm{L}$ of Tween 20). A $120-\mu \mathrm{L}$ quantity of a $10 \mathrm{~g} / \mathrm{L}$ gelatin/PBS solution was added to each well and the plate was incubated at $25^{\circ} \mathrm{C}$ for $2 \mathrm{~h}$, after which it was washed 3 times. One hundred microliters of an antibody (antisera) diluted with PBS was added to each well, and the plate was incubated at $25^{\circ} \mathrm{C}$ for 2 h. After 3 washings, $100 \mu \mathrm{L}$ of alkaline phosphataselabeled goat anti-rabbit Ig (Dako A/S, Glostrup, Denmark) diluted with PBS-Tween was added to each well. The plate was incubated at $25^{\circ} \mathrm{C}$ for $2 \mathrm{~h}$, and the wells were then washed 3 times. One hundred microliters of $1 \mathrm{~g} / \mathrm{L}$ of sodium $p$-nitrophenyl phosphate disodium/diethanolamine hydrochloride buffer ( $\mathrm{pH} 9.8$ ) was added to each well, and the plate was incubated at $25^{\circ} \mathrm{C}$ for 30 min. After the addition of $5 \mathrm{M} \mathrm{NaOH}$ solution (20 $\mu \mathrm{L}$ ) to each well to stop the reaction, the absorbance at $405 \mathrm{~nm}$ was measured using a Bio-Rad 550 microplate reader (Bio-Rad Laboratories Inc., Hercules, CA).

\section{Cell Culture}

A human monocytic leukemia cell line (THP-1) was purchased from the Riken cell bank (Tsukuba, Japan). Cells were grown in RPMI-1640 medium supplemented with $10 \%$ FBS, $100 \mathrm{U} / \mathrm{mL}$ of penicillin, and $100 \mathrm{U} /$ $\mathrm{mL}$ of streptomycin (Gibco, BCL, Burlington, Ontario, $\mathrm{CA})$ at $37^{\circ} \mathrm{C}$ under $5 \% \mathrm{CO}_{2}$ in air. A murine leukemia cell line (L1210) was purchased from the American Type Culture Collection (ATCC, Manassas, VA). Cells were grown in RPMI-1640 medium supplemented with $10 \%$ FBS, $1 \mathrm{~m} M$ sodium pyruvate, and $50 \mathrm{U} / \mathrm{mL}$ of gentamicin at $37^{\circ} \mathrm{C}$ under $5 \% \mathrm{CO}_{2}$ in air. Exponentially growing cells were used in the following experiments.

\section{Measurement of IL-6}

The effect of $\alpha$-LA samples on the LPS-induced IL-6 response in THP-1 cells was investigated according to the method of Mattsby-Baltzer et al. (1996). The THP1 cells were pretreated by adding IFN- $\gamma$ (Sigma-Aldrich Inc.) at a concentration of $200 \mathrm{U} / \mathrm{mL}$ for $18 \mathrm{~h}$ before the cell experiment. Interferon- $\gamma$ increases the sensitivity for stimulation with LPS (Vey et al., 1992). Cells were washed by centrifugation at $200 \times g$ for $10 \mathrm{~min}$ at room temperature. The cell density was adjusted to $1.25 \times$ $10^{6}$ cells/mL using fresh complete medium (RPMI-1640 supplemented with $5 \% \mathrm{FBS})$. The cells $(800 \mu \mathrm{L})$ were added to the wells of a 24-well plate (144530, Nunc $\mathrm{A} / \mathrm{S}$ ), and incubated for $2 \mathrm{~h}$ in the absence and presence of protein samples of different protein concentrations (10 or $100 \mu \mathrm{g} / \mathrm{mL}$ ). The cells were further incubated for $24 \mathrm{~h}$ in the absence and presence of LPS $(0.5 \mu \mathrm{g} / \mathrm{mL})$. The final volume of the media in each well was $1 \mathrm{~mL}$. After the incubation period, the cell culture media were removed and centrifuged at $400 \times g$ for $10 \mathrm{~min}$ at room temperature. Concentration of IL-6 in the supernatant was determined by an IL-6 Human, Biotrak ELISA System (GE Healthcare UK Limited, Buckinghamshire, UK), according to the manufacturer's instructions. The LPS alone served as a control.

\section{Measurement of TNF-a}

The THP-1 cell density was adjusted to $0.2 \times 10^{6}$ cells $/ \mathrm{mL}$ by using fresh complete medium (RPMI1640 medium supplemented with $10 \%$ FBS). The cells $(1 \mathrm{~mL})$ were added to the wells of a 24 -well plate (142475, Nunc A/S) and were differentiated into adherent macrophage-like cells in the presence of phorbol 12 -myristate 13 -acetate $(100 \mathrm{ng} / \mathrm{mL})$. After incubation for $3 \mathrm{~d}$, nonadherent cells were washed away, and the remaining adherent macrophage-like cells were incubated for $2 \mathrm{~h}$ in the absence and presence of protein samples of different concentrations (10 or $100 \mu \mathrm{g} / \mathrm{mL}$ ). The cells were further incubated for $6 \mathrm{~h}$ in the absence and presence of LPS $(100 \mathrm{ng} / \mathrm{mL})$. The final volume of the media in each well was $1 \mathrm{~mL}$. Concentration of TNF- $\alpha$ in the supernatant was determined by a Biotrak ELISA System (GE Healthcare UK Limited), according to the manufacturer's instructions. The LPS alone served as a control.

\section{Measurement of Solubilization of Ca Phosphate}

The preparation of test solutions was conducted according to the procedures for artificial $\mathrm{CN}$ micelles (Aoki, 1989). Forty microliters of $1.0 \mathrm{M}$ potassium 
citrate, $200 \mu \mathrm{L}$ of $0.2 \mathrm{M} \mathrm{CaCl}_{2}$, and $240 \mu \mathrm{L}$ of $0.2 \mathrm{M}$ $\mathrm{K}_{2} \mathrm{HPO}_{4}$ were added to $2 \mathrm{~mL}$ of $4 \%$ protein solution, followed by the addition of $200 \mu \mathrm{L}$ of $0.2 \mathrm{M} \mathrm{CaCl}_{2}$, and $100 \mu \mathrm{L}$ of $0.2 \mathrm{M} \mathrm{K}_{2} \mathrm{HPO}_{4}$. The addition of $200 \mu \mathrm{L}$ of 0.2 $M \mathrm{CaCl}_{2}$, and $100 \mu \mathrm{L}$ of $0.2 M \mathrm{~K}_{2} \mathrm{HPO}_{4}$ was repeated to yield $\mathrm{Ca}$ and $\mathrm{Pi}$ concentrations of 30 and $22 \mathrm{mM}$, respectively. The interval set for the addition was 15 min, and all additions were accompanied by stirring at $\mathrm{pH}$ 6.7. The volume was adjusted to $4 \mathrm{~mL}$ by measuring the weight of the solutions. The prepared solutions were allowed to stand for $20 \mathrm{~h}$ at $25^{\circ} \mathrm{C}$, and then centrifuged at $1,000 \times g$ for $15 \mathrm{~min}$ at $25^{\circ} \mathrm{C}$. The $\mathrm{Ca}$ and $\mathrm{Pi}$ in the supernatant were then determined (the former by using a Hitachi Z-600 atomic absorption spectrophotometer; Hitachi Inc., Tokyo, Japan).

\section{Formation of HAMLET-Like Complex on Oleic Acid-Conditioned Matrices}

The HAMLET-like complex from bovine $\alpha$-LA is called "bovine $\alpha$-LA made lethal to tumor cells" (BAMLET). The BAMLET-like complexes from $\alpha$-LA samples were prepared according to the method of Svensson et al. (2000). A column $(11.3 \times 1.5 \mathrm{~cm})$ packed with DEAETrisacryl M (BioSepra, Villeneuve la Garenne, France) was attached to an HPLC system (pump: PU-2080 plus, UV detector: UV-2075 plus, Jasco) and eluted with a $\mathrm{NaCl}$ gradient (buffer A: $10 \mathrm{~m} M$ Tris- $\mathrm{HCl}, \mathrm{pH}$ 8.5, $0.1 \mathrm{M} \mathrm{NaCl}$; buffer B: $10 \mathrm{~m} M$ Tris-HCl, pH 8.5, 1 $M \mathrm{NaCl}$ ). First, the matrix was conditioned with oleic acid. Twenty milligrams of oleic acid was dissolved in 1 $\mathrm{mL}$ of $99.5 \%$ ethanol by sonication for $3 \mathrm{~min}$ (Branson 3510 bath sonicator, Branson, CT). After addition of $20 \mathrm{~mL}$ of buffer $\mathrm{A}$, the lipid solution was applied to the column and dispersed throughout the matrix by using a NaCl:60-mL linear gradient (100 to $0 \%$ A, 0 to $100 \%$ B). Twenty milligrams of protein sample was dissolved in $40 \mathrm{~mL}$ of buffer A containing $0.08 \mathrm{mM}$ EDTA. The protein solution was applied to the column and eluted with $\mathrm{NaCl}: 80-\mathrm{mL}$ linear gradient (100 to $85 \% \mathrm{~A}, 0$ to $15 \%$ B), $40 \mathrm{~mL}(85 \%$ A, $15 \%$ B), $20 \mathrm{~mL}(20 \%$ A, $80 \%$ $\mathrm{B})$, and $40 \mathrm{~mL}(100 \% \mathrm{~A})$. The protein fraction eluted with high salt content was desalted by dialysis against distilled water and lyophilized.

\section{Apoptosis Assay}

The apoptosis assay was conducted according to the method of Svensson et al. (2000). The L1210 cells were harvested by centrifugation $(400 \times g, 10 \mathrm{~min}$, room temperature), washed in PBS, resuspended in cell culture medium without FBS, seeded into a 24-well microplate (144530, Nunc A/S) at a density of $2 \times 10^{6}$ cells/well, and incubated at $37^{\circ} \mathrm{C}$ under $5 \% \mathrm{CO}_{2}$ in air.
The lyophilized samples were suspended in PBS, and $100-\mu \mathrm{L}$ quantities of these solutions were added to wells at a final protein concentration of 0.03 to $0.06 \mathrm{mg} / \mathrm{mL}$. The protein concentration in the solution was determined using the method of Lowry et al. (1951). After $1 \mathrm{~h}, 100 \mu \mathrm{L}$ of FBS was added to each well at a final concentration of $10 \%$. The final volume of the media in each well was $1 \mathrm{~mL}$. The PBS without BAMLET samples served as a control.

Cell viability was determined by trypan blue exclusion after $5 \mathrm{~h}$ of incubation. For analysis, $50 \mu \mathrm{L}$ of the cell suspension was mixed with $50 \mu \mathrm{L}$ of a $0.5 \%$ trypan blue solution, and the number of stained cells (dead cells) per 100 cells was determined by interference contrast microscopy (Nikon Co. Inc., Tokyo, Japan).

\section{Statistical Analysis}

The data are expressed as mean values with its SD. Significant differences between mean values are determined by Student's $t$-test at the $5 \%$ significance level.

\section{RESULTS AND DISSCUSSION}

\section{Characteristics of Glycated and Phosphorylated $\alpha-L A$}

$\alpha$-Lactalbumin was conjugated with MP (MP- $\alpha-L A)$ at $\mathrm{pH} 8.0$ and $50^{\circ} \mathrm{C}(65 \% \mathrm{RH})$ for $3 \mathrm{~d}$ through the Maillard reaction, and the MP- $\alpha-L A$ was then phosphorylated by dry heating in the presence of MP and pyrophosphate. Table 1 shows some characteristics of the various $\alpha$-LA samples. No sugar was detected in $\alpha$-LA, whereas the sugar content of $\alpha-\mathrm{LA}$ increased to $12.3 \%$ after incubation with $\mathrm{MP}$ at $50^{\circ} \mathrm{C}(65 \% \mathrm{RH})$ for $3 \mathrm{~d}$, and then further still to $22.3 \%$ by dry heating at $\mathrm{pH} 4.0$ and $85^{\circ} \mathrm{C}$ for $5 \mathrm{~d}$ in the presence of MP and pyrophosphate. The number of introduced MP estimated by sugar content (Table 1) was approximately 2.4 for $\mathrm{MP}-\alpha-\mathrm{LA}$, and 4.9 for $\mathrm{PP}-\mathrm{MP}-\alpha-\mathrm{LA}-5 \mathrm{~d}$, respectively. In most foods, the $\varepsilon$-amino group of the Lys residues in proteins is the primary source of reactive amino groups (Ames, 1992). When it was assumed that only the $\varepsilon$-amino group of the Lys residue was modified, the modified Lys residue was $21.8 \%$ for MP- $\alpha-\mathrm{LA}$, and $44.5 \%$ for $\mathrm{PP}-\mathrm{MP}-\alpha-\mathrm{LA}-5 \mathrm{~d}$.

The $\mathrm{P}$ was not detected in $\alpha$-LA, whereas that of MP- $\alpha-L A$ increased to $0.60 \%$ by dry heating at $\mathrm{pH} 4.0$ and $85^{\circ} \mathrm{C}$ for $1 \mathrm{~d}$ in the presence of $\mathrm{MP}$ and pyrophosphate (PP-MP- $\alpha-L A-1 d)$, and further to $1.01 \%$ by dry heating for $5 \mathrm{~d}$ (PP-MP- $\alpha-L A-5 \mathrm{~d})$, which was higher than that of bovine whole CN (Fox, 2003). These results suggested that glycation and phosphorylation occurred effectively in $\alpha-\mathrm{LA}$ as well as in WPI (Li et al., 2005a). 
A)
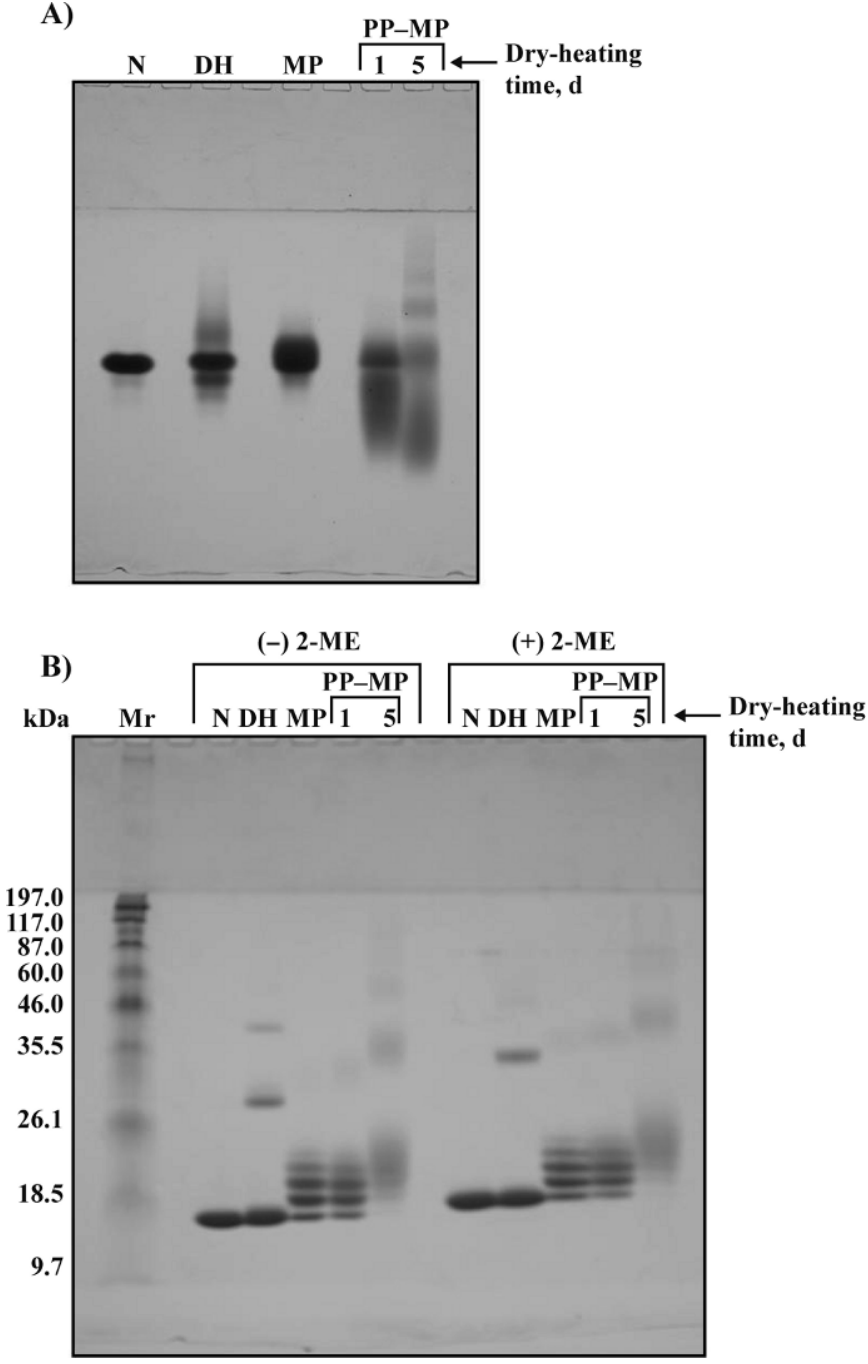

Figure 1. Electrophoretic patterns of native (N), dry-heated (DH), maltopentaose-conjugated (MP), and phosphorylated, maltopentaoseconjugated (PP-MP) $\alpha$-LA: (A) native PAGE $(15 \%$ polyacrylamide gel in the absence of SDS); (B) SDS-PAGE (15\% polyacrylamide gel in the presence of $1.7 \%$ SDS) with (+) and without $(-) 5 \%$ of 2 -mercaptoethanol (2-ME). $\mathrm{Mr}=$ marker protein.

The solubility of $\alpha$-LA samples was measured at $\mathrm{pH}$ 7.0. No significant effect of dry heating in the absence or presence of MP and pyrophosphate on the solubility of $\alpha$-LA was observed, and even when dry heated for $5 \mathrm{~d}$ in the presence of $\mathrm{MP}$ and pyrophosphate after glycation, the solubility of $\alpha$-LA was $98.9 \%$.

Native PAGE was performed to elucidate the changes of charge in protein by glycation and subsequent phosphorylation. Figure 1A shows the native PAGE patterns of N-, DH-, MP-, and PP-MP- $\alpha-L A$. In the present study, a single band was observed in $\mathrm{N}-\alpha-\mathrm{LA}$. In the absence of MP and pyrophosphate, there were almost no changes in the mobility of the band, whereas it decreased by glycation with MP. As glycation substitutes basic AA side-chains, it induces a slight loss of basicity, and consequently, a moderate acidification of the $\alpha$-LA. However, the mobility of MP- $\alpha-L A$ decreased, which might have been caused by the introduction of MP to the $\alpha$-LA and the subsequent increase in the molecular mass. On the other hand, compared with MP- $\alpha-L A$, the mobility of protein increased with an increase in dry-heating time from 1 to $5 \mathrm{~d}$ in the presence of MP and pyrophosphate, and that mobility increase was in agreement with the phosphorylation level (Table 1).

To assess the binding type of aggregates, we performed SDS-PAGE in the absence and presence of 2-ME. It can be clearly seen from Figure 1B that the dry heating induced substantial aggregation in the protein, leading to the coexistence of different populations of monomeric, dimeric, and trimeric $\alpha-\mathrm{LA}$. When $\alpha$-LA was dry heated for $5 \mathrm{~d}$ in the absence of MP and pyrophosphate, the bands of dimers and trimers appeared and relative concentrations of the intensity of the monomer decreased, but there were almost no changes in the mobility of monomer. However, the mobility of monomers decreased by glycation, and 4 bands conjugated with different numbers of MP other than those of monomers were observed in the absence of 2-ME. This observation indicated that the molecular mass of $\alpha-\mathrm{LA}$ increased by conjugation with MP, which might explain why the mobility of $\alpha$-LA was reduced by conjugation with MP in the native PAGE (Figure 1A). In the absence of 2-ME, the intensities of the bands of MP- $\alpha-L A$ decreased with an increase in dry-heating time from 1 to $5 \mathrm{~d}$. In the lanes of $\mathrm{DH}-$, and $\mathrm{PP}-\mathrm{MP}-\mathrm{\alpha}-$ LA-5d, the bands of dimers and trimers were observed in the absence of 2-ME, whereas the band of trimers disappeared and the intensity of the band of dimers decreased in the presence of $2-\mathrm{ME}$, indicating that the formation of polymerization among $\alpha$-LA molecules was caused by a sulfhydryl-disulfide interchange reaction through dry heating in the absence and presence of MP and pyrophosphate. However, some of the aggregates remained undissociated in the presence of $2-\mathrm{ME}$, suggesting that not only disulfide bonds but also other types of bonds were formed by dry heating. Although covalent bonds other than the disulfide bonds formed among proteins by dry heating have been discussed by some researchers (Kato et al., 1989; Watanabe et al., 1999; Chevalier et al., 2001), their structures have not yet been elucidated. It has been reported that crosslinking by amidation between carbonyl and $\varepsilon$-amino groups or by transamidation between such groups with the elimination of ammonia occurs upon severe heat treatment in protein molecules (Feeney, 1975). Thus, covalent bonds such as those mentioned above may be formed in $\alpha$-LA by dry heating in the absence and presence of MP and pyrophosphate. 


\section{Structure of Glycated and Phosphorylated $\alpha-L A$}

We used CD spectroscopy to determine the respective impact of glycation with MP and subsequent phosphorylation by dry heating in the presence of MP and pyrophosphate on the structure of the protein at the secondary folding level. Figure 2 shows the CD spectra of the $\alpha$-LA samples. The CD spectrum of N- $\alpha-L A$ showed double minima, at 208 and $222 \mathrm{~nm}$, indicative of a predominant $\alpha$-helical structure, and these minima were unchanged by glycation alone. However, the minima were slightly increased by dry heating alone, and were further slightly increased by phosphorylation after glycation with the increase of dry-heating time from 1 to $5 \mathrm{~d}$, suggesting that the amount of the $\alpha$-helical secondary structure of $\alpha$-LA was slightly increased by phosphorylation after glycation. These results indicated that the secondary structure of $\alpha-L A$ was not significantly affected by glycation and subsequent phosphorylation.

The Trp fluorescence spectrum was analyzed to evaluate the conformational changes of $\alpha-\mathrm{LA}$ by glycation and subsequent phosphorylation. As shown in Figure 3 , the Trp FI of $\alpha$-LA increased slightly by glycation alone and increased somewhat by dry heating alone. Furthermore, the Trp FI of $\alpha$-LA increased with a red shift by phosphorylation after glycation with the increase of dry-heating time from 1 to $5 \mathrm{~d}$. These results indicated that phosphorylation by dry heating in the presence of MP and pyrophosphate after glycation with MP induced more exposure of Trp residues to solvent (Wijesinha-Bettoni et al., 2007).

To investigate the thermodynamic stability of $\alpha-\mathrm{LA}$ samples, we conducted DSC experiments, and the thermograms of $\alpha$-LA samples are shown in Figure 4. It can been seen that $\mathrm{N}-\alpha-\mathrm{LA}$ had a single peak and the denaturation temperature $\left(\boldsymbol{T}_{\mathrm{d}}\right)$ was $58.4^{\circ} \mathrm{C}$, suggesting that most of the $\alpha$-LA was holo-form (Permyakov and Berliner, 2000). The $T_{\mathrm{d}}$ of $\alpha$-LA was somewhat decreased by dry heating for $5 \mathrm{~d}$ in the absence of MP and

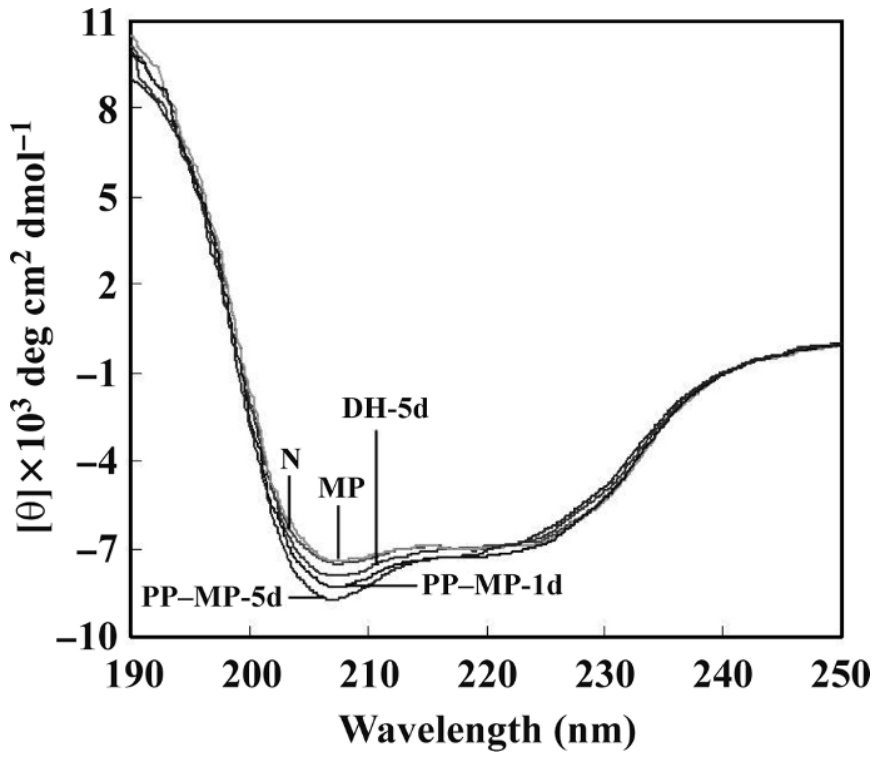

Figure 2. Circular dichroism spectra of native $(\mathrm{N})$, dry-heated (DH), maltopentaose-conjugated (MP), and phosphorylated, maltopentaose-conjugated $(\mathrm{PP}-\mathrm{MP}) \alpha$-LA. Protein samples were $0.1 \mathrm{~g} / \mathrm{L}$ in $50 \mathrm{~m} M$ phosphate buffer ( $\mathrm{pH}$ 7.0). Circular dichroism spectra of $\alpha$-LA samples were measured from 190 to $250 \mathrm{~nm}$.

pyrophosphate. Although the $T_{\mathrm{d}}$ of $\alpha$-LA was slightly increased by glycation with MP, the $T_{\mathrm{d}}$ of MP- $\alpha$-LA was decreased, with a broadening of the peak by dry heating for $5 \mathrm{~d}$ in the presence of MP and pyrophosphate, revealing that the thermodynamic stability of $\alpha$-LA was decreased by phosphorylation after glycation. This decrease in the thermodynamic stability of $\alpha$-LA was considered to be due to a relatively unfolded structure caused by the electrostatic-repulsive force of phosphate groups in the $\alpha$-LA molecule. However, given the slight change in the CD spectra, it was suggested that the changes in gross secondary structure of $\alpha$-LA molecules by phosphorylation after glycation were mild. Thus, molten (partially unfolded) conformations were formed by phosphorylation after glycation (Li et al., 2005b).

Table 1. Some characteristics of $\alpha$-lactalbumins evaluated

\begin{tabular}{lccc}
\hline Sample $^{1}$ & Sugar content $^{2}(\%)$ & P content $^{2}(\%)$ & Solubility $^{2}(\%)$ \\
\hline N- $\alpha$-LA & $0.0 \pm 0.0$ & $0.00 \pm 0.00$ & $99.9 \pm 0.8$ \\
DH- $\alpha-L A-5 d$ & $0.0 \pm 0.0$ & $0.00 \pm 0.00$ & $99.5 \pm 1.2$ \\
MP- $\alpha$-LA & $12.3 \pm 0.5$ & $0.00 \pm 0.00$ & $99.6 \pm 0.6$ \\
PP-MP- $\alpha-L A-1 d$ & $15.3 \pm 0.4$ & $0.60 \pm 0.01$ & $98.4 \pm 1.0$ \\
PP-MP- $\alpha-L A-5 d$ & $22.3 \pm 0.8$ & $1.01 \pm 0.01$ & $98.9 \pm 0.9$ \\
\hline
\end{tabular}

${ }^{1} \mathrm{~N}-\alpha$-LA $=$ native $\alpha$-LA; DH- $\alpha$-LA- $5 \mathrm{~d}=\alpha$-LA incubation at $50^{\circ} \mathrm{C}(65 \% \mathrm{RH})$ for $3 \mathrm{~d}$ and then dry heated at $\mathrm{pH} 4.0$ and $85^{\circ} \mathrm{C}$ for $5 \mathrm{~d}$ in the absence of maltopentaose (MP) and pyrophosphate (PP); MP- $\alpha-\mathrm{LA}=\alpha-\mathrm{LA}$ conjugated with MP by incubation at $50^{\circ} \mathrm{C}(65 \% \mathrm{RH})$ for $3 \mathrm{~d}$; PP-MP- $\alpha-\mathrm{LA}=\mathrm{MP}-\alpha-\mathrm{LA}$ dry heated at $\mathrm{pH}$ 4.0 and $85^{\circ} \mathrm{C}$ for 1 and $5 \mathrm{~d}$ in the presence of $\mathrm{MP}$ and PP.

${ }^{2}$ Each value is the mean with its SD $(\mathrm{n}=3)$. 


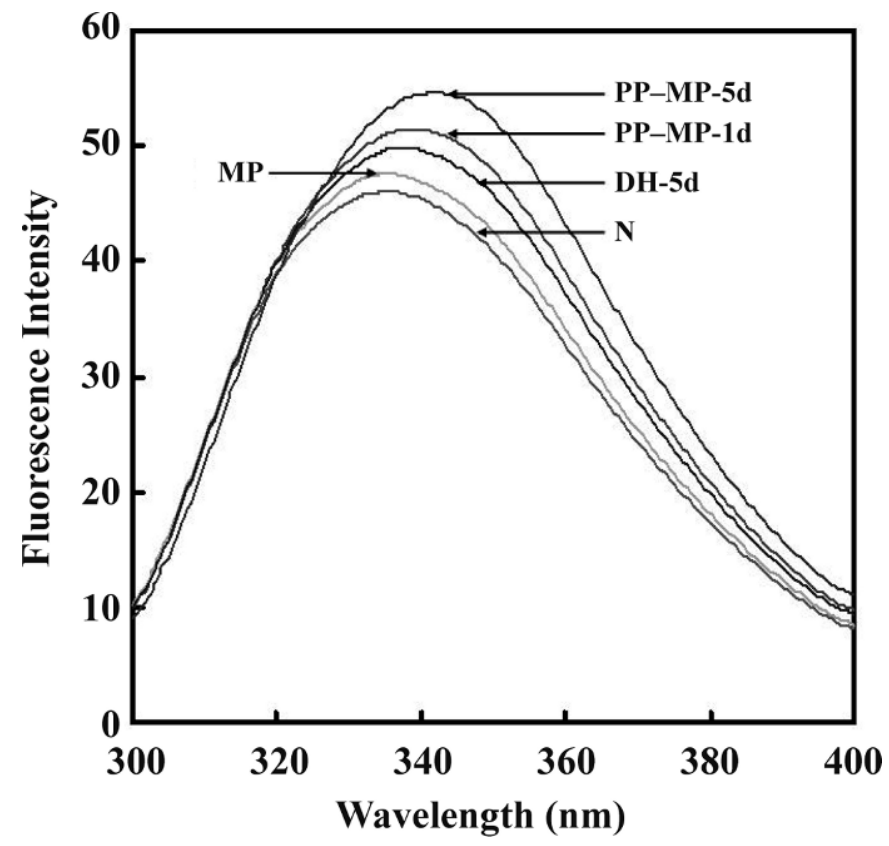

Figure 3. Tryptophan fluorescence spectra of native $(\mathrm{N})$, dryheated (DH), maltopentaose-conjugated (MP), and phosphorylated, maltopentaose-conjugated (PP-MP) $\alpha$-LA. The excitation wavelength was $280 \mathrm{~nm}$, and the emission was scanned from 300 to 400 $\mathrm{nm}$. Fluorescence spectra of $\alpha$-LA samples were measured at $0.1 \mathrm{~g} / \mathrm{L}$ in triplicate.

\section{Physiological Functions of Glycated and Phosphorylated $\alpha-L A$}

The antigenicity of $\alpha$-LA samples was evaluated by measuring the reactivity of 1,000-fold diluted antisera with the antigen $(\alpha-\mathrm{LA})$ adsorbed to the solid phase of a microtitration plate by noncompetitive ELISA. As shown in Figure 5, the reactivity of the $\alpha$-LA was almost unaffected by dry heating in the absence of MP and pyrophosphate. However, the reactivity of the $\alpha-\mathrm{LA}$ was reduced significantly by glycation with MP and was further reduced by phosphorylation after glycation. Immunoglobulin E recognizes specific conformational and linear molecular structures on allergenic proteins. Maynard et al. (1997) suggested the presence of both conformational and linear epitopes on $\alpha$-LA molecules. Thus, these reductions in antigenicity of the $\mathrm{PP}-\mathrm{MP}-\alpha-$ LA were considered to be due to shielding of the linear epitopes by conjugation with MP and unfolding of the conformational epitopes by the electrostatic-repulsive force of the introduced phosphate groups (Enomoto et al. 2007, 2008, 2009).

To assess the effect of glycation and subsequent phosphorylation on the antiinflammatory activity of $\alpha-L A$, we measured the LPS-induced proinflammatory cytokines from THP-1 cells. The monocyte is one of the major IL-6 producing cells. First, the LPS-induced
IL-6 response of THP-1 monocytes after exposure to $\alpha$-LA samples was measured according to the method of Mattsby-Baltzer et al. (1996). In the absence of $\alpha$-LA, the cells produced $91 \mathrm{pg} / \mathrm{mL}$ of IL-6. As shown in Figure $6 \mathrm{~A}$, the $100 \mu \mathrm{g} / \mathrm{mL}$ of $\mathrm{N}-\alpha-\mathrm{LA}$ suppressed the IL- 6 response at $94.2 \%$ of the control, and this suppressive effect was almost unaffected by dry heating in the absence of MP and pyrophosphate. However, compared with $\mathrm{N}-\alpha-\mathrm{LA}$, the IL- 6 response was significantly suppressed by glycation with MP at the protein concentration of $10 \mu \mathrm{g} / \mathrm{mL}$, and was further suppressed by phosphorylation after glycation at the protein concentrations of 10 and $100 \mu \mathrm{g} / \mathrm{mL}$, respectively. When $100 \mu \mathrm{g} / \mathrm{mL}$ of PP-MP- $\alpha-\mathrm{LA}-5 \mathrm{~d}$ was exposed, the IL-6 response was $70.9 \%$ of the control. During the infective process, circulating blood monocytes migrate from the vasculature into the extravascular compartment, where they differentiate into macrophages (Auger and Ross, 1992), and they become activated and produce proinflammatory mediators that contribute to nonspecific immunity. Next, the LPS-induced TNF- $\alpha$ response of THP-1 macrophages after exposure to $\alpha$-LA samples was measured. In the absence of $\alpha$-LA, the cells produced $966 \mathrm{pg} / \mathrm{mL}$ of TNF- $\alpha$. As shown in Figure 6B, the $100 \mu \mathrm{g} / \mathrm{mL}$ of $\mathrm{N}-\alpha-\mathrm{LA}$ suppressed the TNF- $\alpha$ response at $83.8 \%$ of the control, and this suppressive effect was almost unaffected by dry heating in the absence of MP and pyrophosphate. However, compared with N- $\alpha-\mathrm{LA}$,

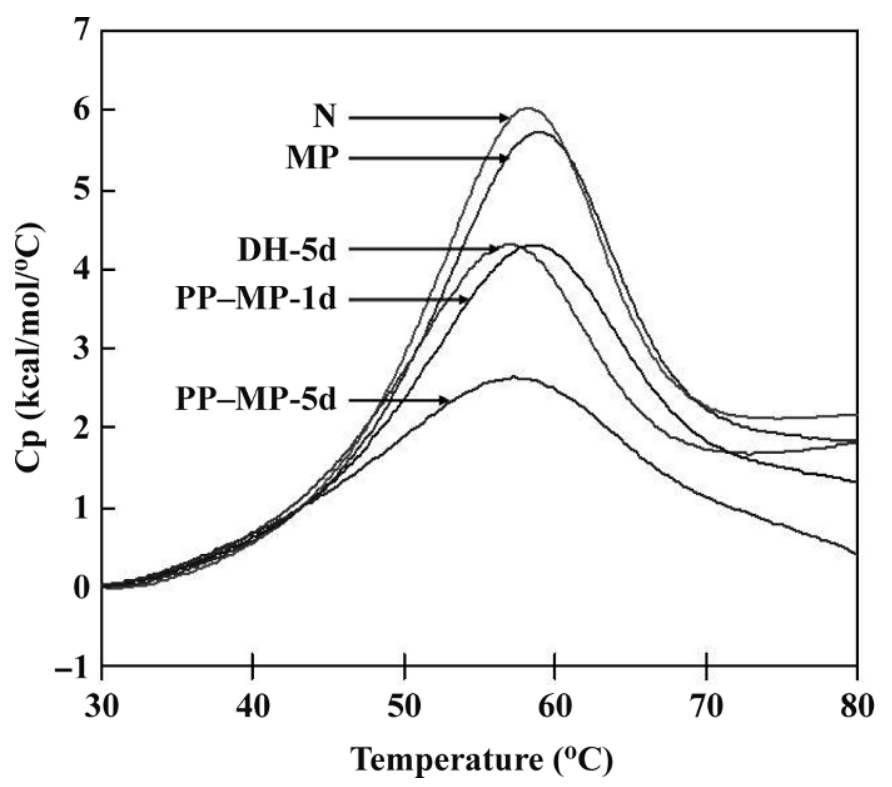

Figure 4. Differential scanning calorimetry profiles of native (N), dry-heated (DH), maltopentaose-conjugated (MP), and phosphorylated, maltopentaose-conjugated (PP-MP) $\alpha$-LA. Differential scanning calorimetry scans were performed with a protein solution of $1 \mathrm{~g} / \mathrm{L}$ in $20 \mathrm{~m} M$ phosphate buffer ( $\mathrm{pH} 7.4$ ). These samples were heated in the calorimeter at a scan rate of $1^{\circ} \mathrm{C} / \mathrm{min}$ over a range of 30 to $80^{\circ} \mathrm{C}$. 


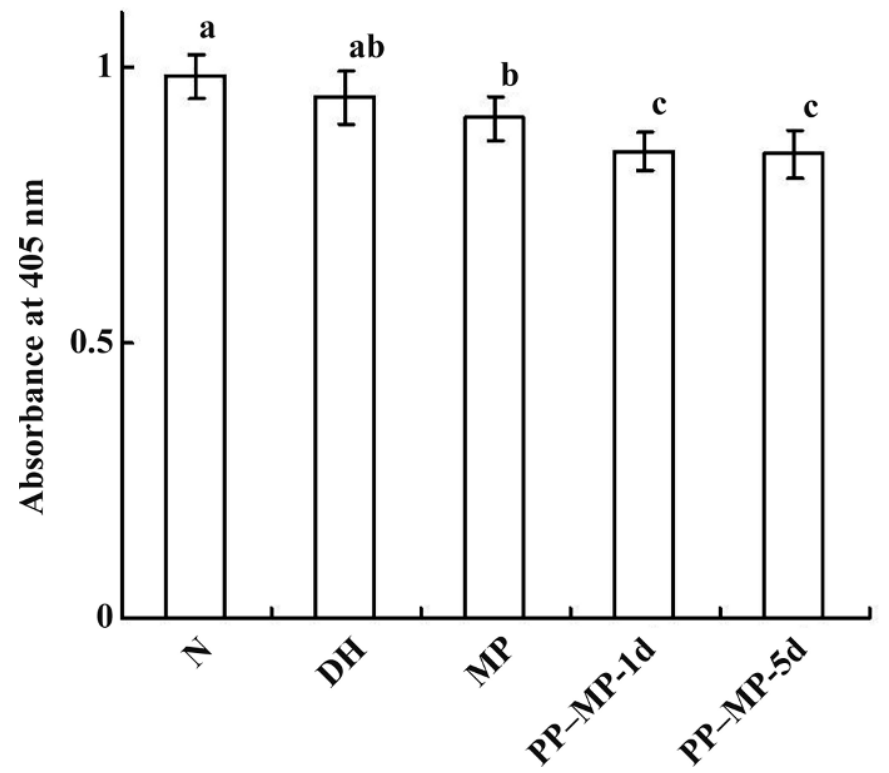

Figure 5. Antigenicity of native (N), dry-heated (DH), maltopentaose-conjugated (MP), and phosphorylated, maltopentaose-conjugated $(\mathrm{PP}-\mathrm{MP}) \alpha-\mathrm{LA}$ in an adult male Japanese white (JW/CSK) rabbit. The anti- $\alpha-\mathrm{LA}$ response after secondary immunization of the rabbit was evaluated by noncompetitive ELISA, and the results are shown as ELISA values (absorbance at $405 \mathrm{~nm}$ ). Each value represents the mean $\pm \mathrm{SD}(\mathrm{n}=5)$. Values with different letters are significantly different at $P<0.05$ as determined by Student's $t$-test.

the TNF- $\alpha$ response was significantly suppressed by glycation with MP at the protein concentration of 100 $\mu \mathrm{g} / \mathrm{mL}$ and was further suppressed by phosphorylation after glycation at the protein concentrations of 10 and $100 \mu \mathrm{g} / \mathrm{mL}$, respectively. When $100 \mu \mathrm{g} / \mathrm{mL}$ of $\mathrm{PP}-\mathrm{MP}-\alpha-\mathrm{LA}-5 \mathrm{~d}$ was exposed, the TNF- $\alpha$ response was $65.3 \%$ of the control. These results suggested that the antiinflammatory activity of $\alpha$-LA was significantly enhanced by glycation with MP and further enhanced by phosphorylation after glycation. Proinflammatory cytokines, such as IL-6 and TNF- $\alpha$, are key molecules in human acute or chronic inflammatory diseases (Matsuda and Hattori, 2006; Möller and Villiger, 2006). It is known that activation of the nuclear factor- $\kappa \mathrm{B}$ pathway is involved in the pathogenesis of these inflammatory diseases (Yamamoto and Gaynor, 2001; Matsuda and Hattori, 2006). Further studies are in progress in our laboratory to evaluate the effect of glycation and subsequent phosphorylation on the antiinflammatory activity of $\alpha$-LA in vivo by using a rodent model.

The solubilization of the Ca phosphate of $\alpha$-LA was examined by using the method for artificial CN micelles, where the final concentrations of $\mathrm{Ca}, \mathrm{Pi}$, and citrate were 30,22 , and $10 \mathrm{~m} M$, respectively. The solubilized $\mathrm{Ca}$ and $\mathrm{Pi}$ were estimated from the difference between their soluble concentrations in the solutions with and without protein. As shown in Figure 7, in the case of
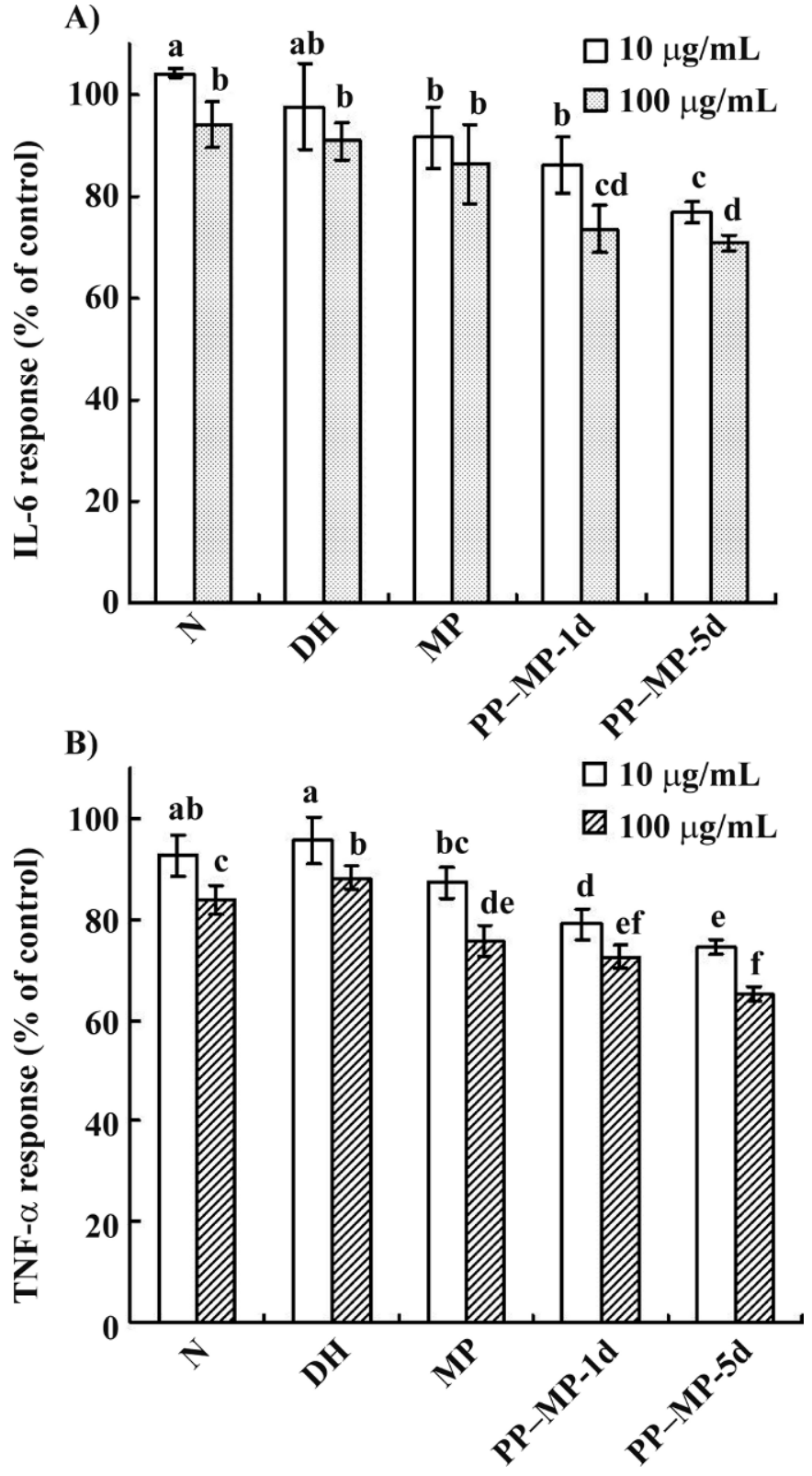

Figure 6. Effect of native (N), dry-heated (DH), maltopentaoseconjugated (MP), and phosphorylated, maltopentaose-conjugated (PP-MP) $\alpha$-LA on the (A) IL-6 response of THP-1 monocytes and (B) tumor necrosis factor (TNF)- $\alpha$ response of THP-1 macrophages after stimulation with LPS. The control is media with LPS and without protein. Each datum is expressed as a percentage of the control value. Each value shows the mean $\pm \mathrm{SD}(\mathrm{n}=5)$. Values with different letters are significantly different at $P<0.05$ as determined by Student's $t$-test.

$\mathrm{N}-$, DH-, and MP- $\alpha-\mathrm{LA}$, a slight increase in solubilized $\mathrm{Ca}$ and a slight decrease in solubilized phosphate were observed. In general, the soluble $\mathrm{Ca}$ and $\mathrm{Pi}$ in the solution with protein were higher than those without protein. However, in the present study, solubilized Pi in the solution with $\alpha$-LA was lower than that without 
Table 2. The viability ${ }^{1}$ of L1210 cells after exposure to bovine $\alpha$-LA made lethal to tumor cells (BAMLET) at different concentrations ( 0.03 to $0.06 \mathrm{mg} / \mathrm{mL}$ ) from different $\alpha$-LA

\begin{tabular}{lrcrc}
\hline & \multicolumn{4}{c}{ Cell viability $(\%)$} \\
\cline { 2 - 4 } Sample $^{2}$ & $0.03 \mathrm{mg} / \mathrm{mL}$ & $0.04 \mathrm{mg} / \mathrm{mL}$ & $0.05 \mathrm{mg} / \mathrm{mL}$ & $0.06 \mathrm{mg} / \mathrm{mL}$ \\
\hline Control & $98.1 \pm 2.8$ & $97.5 \pm 1.7$ & $97.2 \pm 3.1$ & $98.2 \pm 1.4$ \\
N-BAMLET & $3.4 \pm 1.5$ & $0.4 \pm 0.4$ & $0.1 \pm 0.2$ & $0.0 \pm 0.0$ \\
DH-5d-BAMLET & $3.1 \pm 1.9$ & $0.4 \pm 0.4$ & $0.0 \pm 0.0$ & $0.0 \pm 0.0$ \\
MP-BAMLET & $12.3 \pm 1.9$ & $4.1 \pm 1.9$ & $0.9 \pm 0.6$ & $0.2 \pm 0.3$ \\
PP-MP-1d-BAMLET & $22.9 \pm 1.5$ & $10.5 \pm 4.9$ & $5.1 \pm 1.6$ & $1.2 \pm 0.4$ \\
PP-MP-5d-BAMLET & $30.2 \pm 3.6$ & $18.8 \pm 0.9$ & $9.5 \pm 1.1$ & $3.8 \pm 0.9$ \\
\hline
\end{tabular}

${ }^{1}$ Each value represents the mean $\pm \mathrm{SD}(\mathrm{n}=3)$.

${ }^{2}$ Control = PBS without BAMLET; N-BAMLET = complex of native $(\mathrm{N}) \alpha-\mathrm{LA}$ and oleic acid; DH-5dBAMLET $=$ a complex of dry-heated $(\mathrm{DH}) \alpha$-LA and oleic acid; MP-BAMLET $=$ a complex of maltopentaoseconjugated (MP) $\alpha$-LA and oleic acid; PP-MP-BAMLET = a complex of phosphorylated and MP-conjugated $(\mathrm{PP}-\mathrm{MP}) \alpha-\mathrm{LA}$ and oleic acid.

$\alpha$-LA. This was considered to be due to the formation of insoluble Ca phosphate between Ca binding to $\alpha$-LA and added phosphate. In the presence of $2 \%$ protein, $\mathrm{PP}-\mathrm{MP}-\alpha-\mathrm{LA}-5 \mathrm{~d}$ solubilized $13.4 \mathrm{~m} M \mathrm{Pi}$ and 20.5 $\mathrm{m} M \mathrm{Ca}$, indicating that the Ca phosphate-solubilizing ability of $\alpha$-LA was enhanced by phosphorylation after glycation. Thus, $\mathrm{PP}-\mathrm{MP}-\alpha-\mathrm{LA}$ may be expected to enhance the absorption of Ca.

To evaluate the apoptotic activity of $\alpha$-LA after glycation and subsequent phosphorylation, we prepared BAMLET-like complexes of $\alpha$-LA samples and oleic acid, and the viability of L1210 cells after exposure to

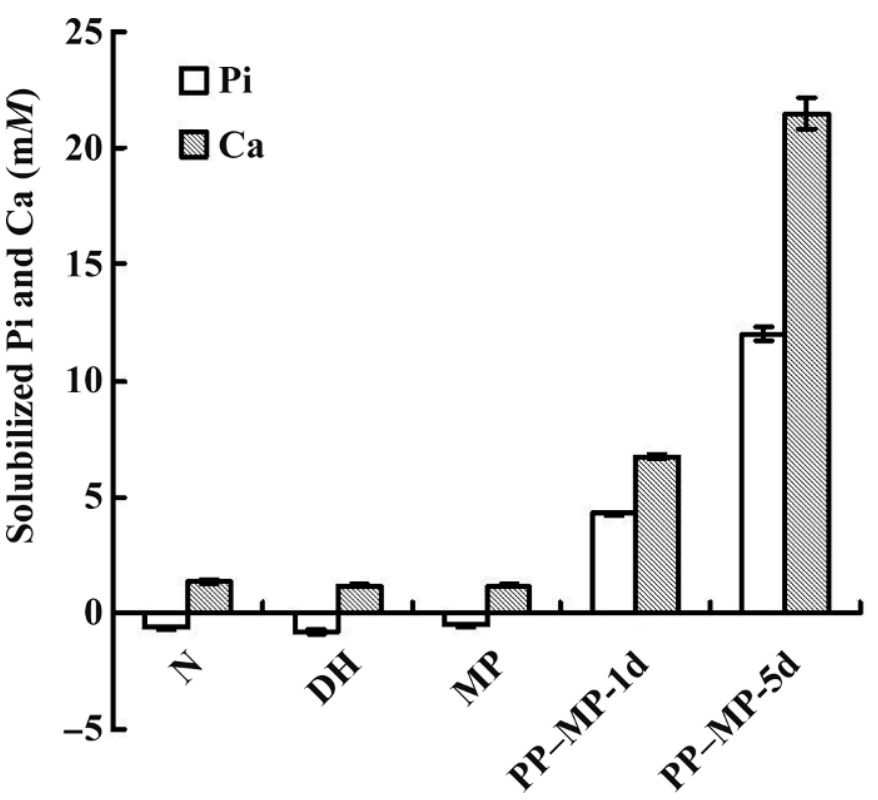

Figure 7. Calcium phosphate-solubilizing ability of native $(\mathrm{N})$, dry-heated (DH), maltopentaose-conjugated (MP), and phosphorylated, maltopentaose-conjugated (PP-MP) $\alpha$-LA. The test solution contained $20 \mathrm{~g} / \mathrm{L}$ of protein, $30 \mathrm{~m} M$ Ca, $22 \mathrm{~m} M$ inorganic $\mathrm{P}(\mathrm{Pi})$, and $10 \mathrm{~m} M$ citrate, with $\mathrm{pH}$ adjusted to 6.7 with $1 \mathrm{M} \mathrm{KOH}$. Each column shows the mean values $\pm \mathrm{SD}(\mathrm{n}=3)$.
BAMLET-like complexes at various protein concentrations was measured. The fragmentation DNA, which is a characteristic feature of apoptosis, was observed in all BAMLET-like complexes (data not shown). As shown in Table 2, in the absence of BAMLET-like complexes, most of the cells were living, whereas most of the cells were dead in their presence at the levels tested. The N-BAMLET decreased cell viability to $3.4 \%$ at a 0.03 $\mathrm{mg} / \mathrm{mL}$ protein concentration, which was an end point, and there was no effect of dry heating in the absence of MP and pyrophosphate. This activity was decreased by glycation and subsequent phosphorylation, and the end points of the protein concentration of MP-BAMLET and PP-MP-5d-BAMLET were 0.04 and $0.06 \mathrm{mg} / \mathrm{mL}$, respectively. It was unclear why the apoptotic activity of the complex of $\alpha$-LA and oleic acid was decreased by glycation and subsequent phosphorylation.

\section{CONCLUSIONS}

We have shown that $\alpha$-LA was effectively phosphorylated by dry heating in the presence of pyrophosphate after glycation with MP. Although the secondary structural change of $\alpha$-LA was slight, the Trp FI of $\alpha$-LA was increased by phosphorylation after glycation. In addition, DSC thermograms showed that the $T_{\mathrm{d}}$ of MP- $\alpha$-LA was decreased by phosphorylation, indicating that molten (partially unfolded) conformations of $\alpha$-LA were formed by dry heating in the presence of pyrophosphate after glycation with MP. Although the apoptotic activity of $\alpha$-LA was reduced by glycation and subsequent phosphorylation, the antiinflammatory activity of $\alpha-\mathrm{LA}$ was significantly enhanced by glycation and further enhanced by phosphorylation after glycation, and the Ca phosphate-solubilizing ability of $\alpha$-LA was enhanced by phosphorylation. The antigenicity of $\alpha$-LA was significantly reduced by glycation and subsequent phosphorylation. Thus, phosphorylation 
by dry heating in the presence of pyrophosphate after glycation with MP seems to be a useful method for improving some physiological functions of $\alpha$-LA.

\section{ACKNOWLEDGMENTS}

This work was supported by a grant-in-aid (17580238) from the Ministry of Education, Culture, Sports, Science, and Technology of Japan. We thank Kentaro Morizane (Nihon Shokken Co., Ehime, Japan) for conducting the DSC experiment.

\section{REFERENCES}

Ames, J. M. 1992. The Maillard reaction. Pages 99-153 in Biochemistry of Food Proteins. B. J. F. Hudson, ed. Elsevier Science Publishers, London, UK.

Aoki, T. 1989. Incorporation of individual casein constituents into casein aggregates cross-linked by colloidal calcium phosphate in artificial casein micelles. J. Dairy Res. 56:613-618.

Aoki, T., T. Fukumoto, T. Kimura, Y. Kato, and T. Matsuda. 1994. Whey protein- and egg white protein-glucose 6-phosphate conjugates with calcium phosphate-solubilizing properties. Biosci. Biotechnol. Biochem. 58:1727-1728.

Aoki, T., Y. Hiidome, Y. Sugimoto, H. R. Ibrahim, and Y. Kato. 2001. Modification of ovalbumin with oligogalacturonic acid through the Maillard reaction. Food Res. Int. 34:127-132.

Aoki, T., K. Kitahata, T. Fukumoto, Y. Sugimoto, H. R. Ibrahim, T. Kimura, Y. Kato, and T. Matsuda. 1997. Improvement of functional properties of $\beta$-lactoglobulin by conjugation with glucose-6-phosphate through the Maillard reaction. Food Res. Int. 30:401-406.

Armstrong, J. M., H. A. McKenzie, and W. H. Sawyer. 1967. On the fractionation of $\beta$-lactoglobulin and $\alpha$-lactalbumin. Biochim. Biophys. Acta 147:60-72.

Auger, M. J., and J. A. Ross. 1992. The biology of the macrophage. Pages 3-74 in The macrophage. C. E. Lewis and J. O. McGee, ed. IRL Press, New York, NY.

Brodbeck, U., W. L. Denton, N. Tanahashi, and K. E. Ebner. 1967. The isolation and identification of the $\mathrm{B}$ protein of lactose synthetase as $\alpha$-lactalbumin. J. Biol. Chem. 242:1391-1397.

Chen, P. S., T. Y. Toribara, and H. Warner. 1956. Microdetermination of phosphorus. Anal. Chem. 28:1756-1758.

Chevalier, F., J. M. Chobert, D. Mollé, and T. Haertlé. 2001. Maillard glycation of $\beta$-lactoglobulin with several sugars: Comparative study of the properties of the obtained polymers and of the substituted sites. Lait 81:651-666.

Chobert, J. M. 2003. Milk protein modification to improve functional and biological properties. Pages 1-60 in Advances in Food and Nutrition Research. Vol. 47. S. L. Taylor, ed. Academic Press, New York, NY.

Cross, M. L., and H. S. Gill. 2000. Immunomodulatory properties of milk. Br. J. Nutr. 84:S81-S89.

Dubois, M., K. A. Gilles, J. K. Hamilton, P. A. Rebers, and F. Smith. 1956. Colorimetric method for determination of sugars and related substances. Anal. Chem. 28:350-356.

Enomoto, H., C. P. Li, K. Morizane, H. R. Ibrahim, Y. Sugimoto, S. Ohki, H. Ohtomo, and T. Aoki. 2007. Glycation and phosphorylation of $\beta$-lactoglobulin by dry-heating: Effect on protein structure and some properties. J. Agric. Food Chem. 55:2392-2398.

Enomoto, H., C. P. Li, K. Morizane, H. R. Ibrahim, Y. Sugimoto, S. Ohki, H. Ohtomo, and T. Aoki. 2008. Improvement of functional properties of bovine serum albumin through phosphorylation by dry-heating in the presence of pyrophosphate. J. Food Sci. 73:C84-C91.
Enomoto, H., S. Nagae, Y. Hayashi, C. P. Li, H. R. Ibrahim, Y. Sugimoto, and T. Aoki. 2009. Improvement of functional properties of egg white protein through glycation and phosphorylation by dry-heating. Asian-australas. J. Anim. Sci. 22:591-597.

Feeney, R. E. 1975. Chemical changes in food proteins. Pages 233-254 in Evaluation of Proteins for Humans. C. E. Bodwell, ed. AVI Publishers, Westport, CT.

FitzGerald, R. J., B. A. Murray, and D. J. Walsh. 2004. Hypotensive peptides from milk proteins. J. Nutr. 134:980S-988S.

Fox, P. F. 2003. Milk proteins: General and historical aspects. Pages 1-41 in Advanced Dairy Chemistry. Vol. 1. P. F. Fox and P. L. H. McSweeney, ed. Plenum Publishers, New York, NY.

Kato, A., H. R. Ibrahim, H. Watanabe, K. Honma, and K. Kobayashi. 1989. New approach to improve the gelling and surface functional properties of dried egg white by heating in dry state. J. Agric. Food Chem. 37:433-437.

Kato, Y., T. Aoki, N. Kato, R. Nakamura, and T. Matsuda. 1995. Modification of ovalbumin with glucose-6-phosphate by aminocarbonyl reaction. Improvement of protein heat stability and emulsifying activity. J. Agric. Food Chem. 43:301-305.

Kume, H., K. Okazaki, and H. Sasaki. 2006. Hepatoprotective effects of whey protein on $\mathrm{D}^{\text {-galactosamine-induced hepatitis and liver }}$ fibrosis in rats. Biosci. Biotechnol. Biochem. 70:1281-1285.

Laemmli, U. K. 1970. Cleavage of structural proteins during the assembly of the head of bacteriophage T4. Nature 227:680-685.

Li, C. P., H. Enomoto, S. Ohki, H. Ohtomo, and T. Aoki. 2005a. Improvement of functional properties of whey protein isolate through glycation and phosphorylation by dry heating. J. Dairy Sci. 88:4137-4145.

Li, C. P., Y. Hayashi, H. Shinohara, H. R. Ibrahim, Y. Sugimoto, J. Kurawaki, N. Matsudomi, and T. Aoki. 2005b. Phosphorylation of ovalbumin by dry-heating in the presence of pyrophosphate: Effect on protein structure and some properties. J. Agric. Food Chem. 53:4962-4967.

Li, C. P., H. R. Ibrahim, Y. Sugimoto, H. Hatta, and T. Aoki. 2004. Improvement of functional properties of egg white protein through phosphorylation by dry-heating in the presence of pyrophosphate. J. Agric. Food Chem. 52:5752-5758.

Li, C. P., A. S. Salvador, H. R. Ibrahim, Y. Sugimoto, and T. Aoki. 2003. Phosphorylation of egg white proteins by dry-heating in the presence of phosphate. J. Agric. Food Chem. 51:6808-6815.

Lowry, O. H., N. J. Rosebrough, A. L. Farr, and R. J. Randall. 1951. Protein measurement with the folin phenol reagent. J. Biol. Chem. 193:265-275

Markus, C. R., B. Olivier, G. E. M. Panhuysen, J. V. D. Gugten, M. S. Alles, A. Truiten, H. G. M. Westenberg, D. Fekkes, H. F. Koppeschaar, and E. E. H. F. de Haan. 2000. The bovine protein $\alpha$-lactalbumin increases the plasma ratio of tryptophan to the other large neutral amino acids, and in vulnerable subjects raises brain serotonin activity, reduces cortisol concentration, and improves mood under stress. Am. J. Clin. Nutr. 71:1536-1544.

Matheis, G., and J. R. Whitaker. 1984. Chemical phosphorylation of food proteins: An overview and a prospectus. J. Agric. Food Chem. 32:699-705.

Matsuda, N., and Y. Hattori. 2006. Systemic inflammatory response syndrome (SIRS): Molecular pathophysiology and gene therapy. J. Pharmacol. Sci. 101:189-198.

Matsumoto, H., Y. Shimokawa, Y. Ushida, T. Toida, and H. Hayasawa. 2001. New biological function of bovine alpha-lactalbumin: Protective effect against ethanol- and stress-induced gastric mucosal injury in rats. Biosci. Biotechnol. Biochem. 65:11041111.

Mattsby-Baltzer, I., A. Roseanu, C. Motas, J. Elverfors, I. Engberg, and L. A. Hanson. 1996. Lactoferrin or a fragment thereof inhibits the endotoxin-induced interleukin-6 response in human monocytic cells. Pediatr. Res. 40:257-262.

Maynard, F., R. Jost, and J.-M. Wal. 1997. Human IgE binding capacity of tryptic peptides from bovine $\alpha$-lactalbumin. Int. Arch. Allergy Immunol. 113:478-488. 
Möller, B., and P. M. Villiger. 2006. Inhibition of IL-1, IL-6, and $\mathrm{TNF}-\alpha$ in immune-mediated inflammatory diseases. Springer Semin. Immunopathol. 27:391-408.

Ouchterlony, O. 1949. Antigen-antibody reactions in gels. Acta Pathol. Microbiol. Scand. 26:507-515.

Pellegrini, A., U. Thomas, N. Bramaz, P. Hunziker, and R. von Fellenberg. 1999. Isolation and identification of three bactericidal domains in the bovine $\alpha$-lactalbumin molecule. Biochim. Biophys. Acta 1426:439-448.

Permyakov, E. A., and L. J. Berliner. 2000. $\alpha$-Lactalbumin: Structure and function. FEBS Lett. 473:269-274.

Pettersson, J., A.-K. Mossoberg, and C. Svanborg. 2006. $\alpha$-Lactalbumin species variation, HAMLET formation, and tumor cell death. Biochem. Biophys. Res. Commun. 345:260-270.

Seguro, K., and M. Motoki. 1989. Enzymatic phosphorylation of soybean proteins by protein kinase. Agric. Biol. Chem. 53:32633268.

Shah, N. P. 2000. Effects of milk-derived bioactives: An overview. Br. J. Nutr. 84(Suppl. 1):S3-S10.

Sitohy, M., J. M. Chobert, and T. Haertlé. 1995. Phosphorylation of $\beta$-lactoglobulin under mild conditions. J. Agric. Food Chem. $43: 59-62$.

Sternhagen, L. G., and J. C. Allen. 2001. Growth rates of a human colon adenocarcinoma cell line are regulated by the milk protein $\alpha$-lactalbumin. Adv. Exp. Med. Biol. 501:115-120.

Svensson, M., A. Håkansson, A. K. Mossberg, S. Linse, and C. Svanborg. 2000. Conversion of alpha-lactalbumin to a protein inducing apoptosis. Proc. Natl. Acad. Sci. USA 97:4221-4226.
Vey, E., J.-M. Zhang, and J.-M. Dayer. 1992. IFN- $\gamma$ and $1,25(\mathrm{OH})_{2} \mathrm{D}_{3}$ induce on THP-1 cells distinct patterns of cell surface antigen expression, cytokine production, and responsiveness to contact with activated T cells. J. Immunol. 149:2040-2046.

Vojdani, F., and J. R. Whitaker. 1996. Phosphorylation of proteins and their functional and structural properties. ACS Symp. Ser. 650:210-229.

Watanabe, K., J. Q. Xu, and M. Shimoyamada. 1999. Inhibiting effects of egg white dry-heated at $120^{\circ} \mathrm{C}$ on heat aggregation and coagulation of egg white and characteristics of dry-heated egg white. J. Agric. Food Chem. 47:4083-4088.

Wijesinha-Bettoni, R., C. Gao, J. A. Jenkins, A. R. Mackie, P. J. Wilde, E. N. C. Mills, and L. J. Smith. 2007. Heat treatment of bovine $\alpha$-lactalbumin results in partially folded, disulfide bond shuffled states with enhanced surface activity. Biochemistry 46:9774-9784.

Yamaguchi, M., and M. Uchida. 2007. o-Lactalbumin suppresses interleukin-6 release after intestinal ischemia/reperfusion via nitric oxide in rats. Inflammopharmacology 15:43-47.

Yamamoto, Y., and R. B. Gaynor. 2001. Therapeutic potential of inhibition of the NF- $\kappa$ B pathway in the treatment of inflammation and cancer. J. Clin. Invest. 107:135-142.

Ye, X., S. Yoshida, and T. B. Ng. 2000. Isolation of lactoperoxidase, lactoferrin, $\alpha$-lactalbumin, $\beta$-lactoglobulin A from bovine rennet whey using ion exchange chromatography. Int. J. Biochem. Cell Biol. 32:1143-1150. 